\title{
INTERPRETATION OF MULTIPLE BIOPSIES OF SYNOVIAL TISSUE IN RHEUMATIC DISEASES*
}

\author{
BY \\ B. CRUICKSHANK \\ From the Department of Pathology and the Rheumatic Research Unit, \\ University of Edinburgh
}

(RECEIVED FOR PUBLICATION JANUARY 1, 1952)

The alternating clinical activity and remission which characterize such chronic rheumatic diseases as rheumatoid arthritis, ankylosing spondylitis, systemic lupus erythematosus, and gout are reflected in the histopathology of the synovial tissue. Recurrent phases of inflammation and healing produce a complex picture in all except very early cases. It is no new observation that histological examination, by itself, gives no indication of the duration of the disease. Previous workers have also mentioned the fact that different parts of the same joint show varying appearances (Allison and Ghormley, 1931; Parker and Keefer, 1935; Ghormley, 1938; Jordan, 1938; Rosenberg, 1949), but have laid little stress on this feature.

The introduction of cortisone and ACTH to clinical medicine and the production of a punch biopsy instrument for use in joints (Polley and Bickel, 1951) have stimulated interest in the histopathology of synovial tissue in the chronic rheumatic diseases. The use of the hormones raises the question whether or not the clinical improvement induced by them is associated with changes in the tissues. The use of the punch biopsy instrument has provided the clinician and the pathologist with a ready means of obtaining synovial tissue from joints. Several reports have already appeared in which it is claimed that synovial tissue taken during, or after, the administration of cortisone or ACTH in rheumatoid arthritis shows changes attributable to these hormones. Although the authors of some of these reports are cautious about the interpretation of the histological appearances (Giansiracusa and others, 1951), others accept decrease in the amount of inflammation, oedema, necrosis, or surface hyperplasia as due to the hormones (Hench and others, 1950).

The purpose of this study is to demonstrate the variations in the histopathology of synovial tissue taken at the same time from different parts of joints in these diseases. Particular attention has been paid to features which might be interpreted as an effect of treatment with drugs.

\section{Material}

Synovial tissue was obtained at autopsy or open operation from 35 joints in cases of rheumatoid arthritis, consisting of three shoulders, three elbows, the proximal interphalangeal joint of one finger, and 28 knees. Blocks werè taken from the suprapatellar pouch, the medial or lateral compartment, and the infrapatellar fat pad of each knee, and, in nine cases, two adjacent blocks were taken from one or other of these regions. An average of three blocks was taken from different parts of the other joints.

Multiple blocks were also taken from one sternoclavicular joint, four hips, and one

* Paper read to the Heberden Society on December 7, 1951. 
knee in ankylosing spondylitis; from one elbow and nine knees in rheumatic fever; from four knees in systemic lupus erythematosus; from one knee in gout; and from four knees in polyarteritis nodosa.

All blocks were embedded in paraffin and routine haematoxylin and eosin sections were studied. Comparison of the appearances in different sections in rheumatoid arthritis was made by observing the occurrence of the features regarded by Collins (1949) as characteristic of that condition. The presence or absence of necrosis and the degree of fibrosis were also noted. The same criteria were applied in ankylosing spondylitis, for the lesions in that condition are similar to those of rheumatoid arthritis (Cruickshank, 1951). In the other diseases, the occurrence and degree of proliferation, inflammation, necrosis, and fibrosis were noted. In assessing variations in the histological appearances in these diseases, due consideration was given to the normal variations in histology in synovial tissue in different parts of the joints (Key, 1932).

\section{Results}

Rheumatoid Arthritis.-In sixteen of the joints, the various sections showed the same features, or differed only in minor points, such as variations in the degree and extent of surface hyperplasia or the degree of oedema and congestion. Nine joints showed more noticeable variations, such as the presence of necrosis in only one section, the presence of diffuse granulation tissue alternating with the more typical appearances or variations in the number and distribution of lymphocytes and plasma cells.

In ten of the joints, there were major variations in the histological appearances.

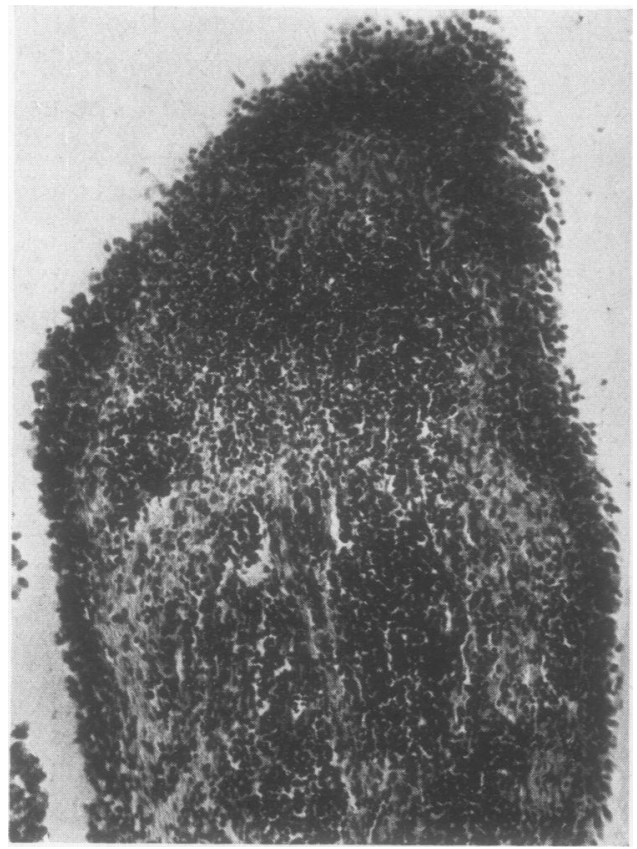

FIG. 1.-Synovial tissue from right knee. Male, aged 49. Rheumatoid arthritis affected the knee for 11 years; no drug treatment. One of many villi, showing hyperplasia of surface cells, oedema, congestion, and massive infiltration with round cells, including large foci. $(\times 100$. $)$

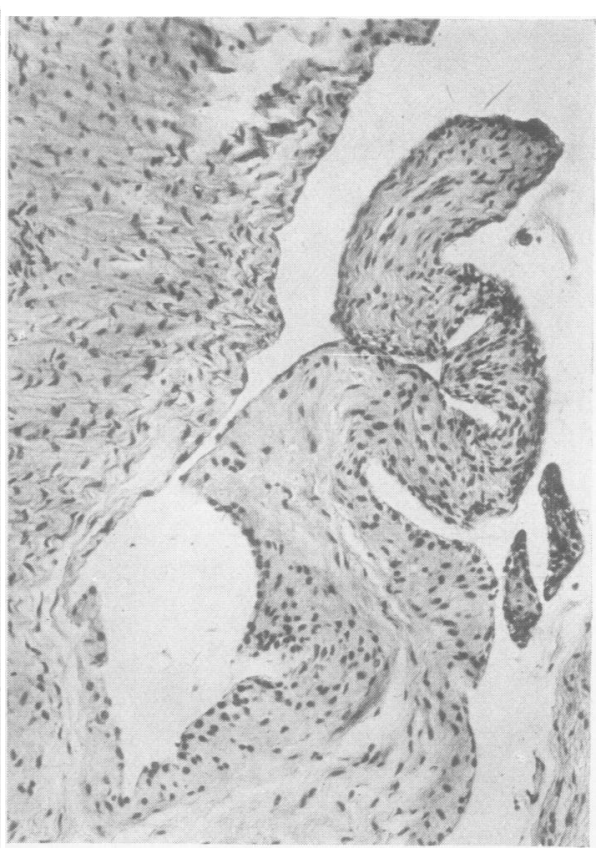

Fig. 2.-Same case as Fig. 1. Section from adjacent block, showing marked fibrosis. ( $\times 100$. 


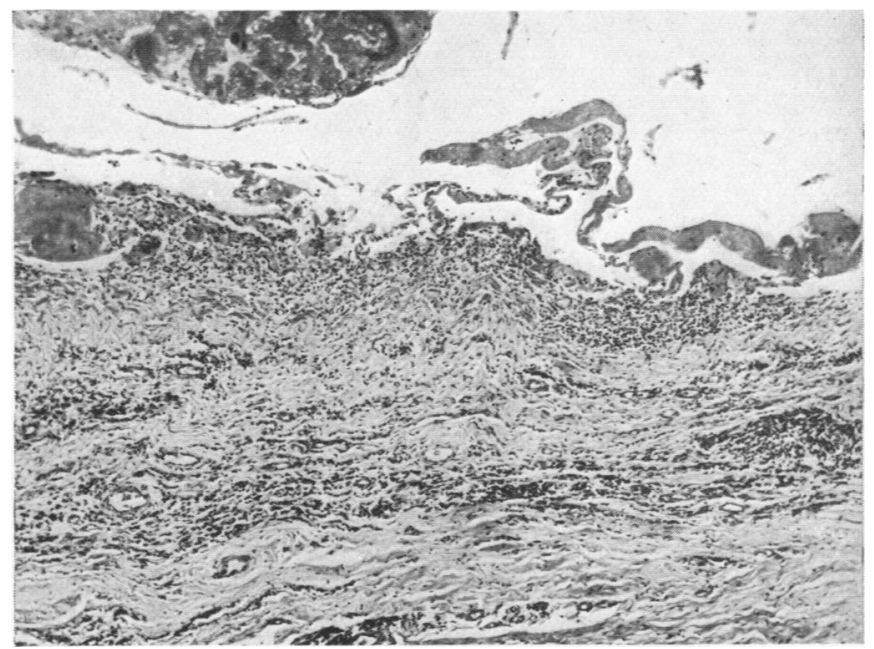

FIG. 3.-Synovial tissue from right knee. Female, aged 75. Rheumatoid arthritis had affected the knee for 2 years; no drug treatment. Extensive necrosis (top), diffuse round-cell infiltration, congestion, and some fibrosis. $(\times 50$. $)$

Fig. 4.--Same case as Fig. 3. Large villous, showing fine fibrosis superimposed upon diffuse round-cell infiltration. $(\times 50$.

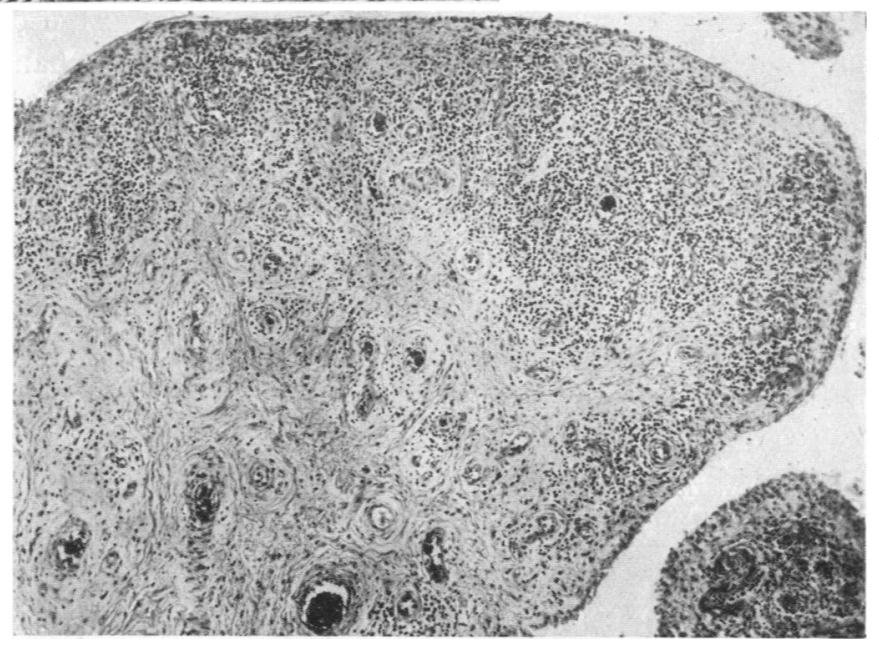

For example, in one knee, one section showed marked hyperplasia and intense inflammation (Fig. 1), whereas these features were absent in another section, which showed well-marked fibrosis (Fig. 2). In another knee, fibrosis was predominant in one section, slight in another, and absent from a third. Three sections from an elbow showed, respectively, marked inflammation without fibrosis, slight inflammation without fibrosis, and marked fibrosis without inflammation. Variations in the relative degrees of inflammation and fibrosis, which might be interpreted as indicative, respectively, of activity and healing, were seen in eight joints (Figs 1-4). Such variations were seen not only in blocks from different regions of a joint, but also sometimes in adjacent blocks from the same region of a joint, and occasionally in a single section.

The cases of rheumatoid arthritis were analysed to see if the histological appearances could be correlated with the duration, stage (Steinbrocker and others, 1949), or clinical activity of the disease in the affected joint, or with drug therapy. The number of cases studied was too small to permit statistical analysis, but certain 
TABLE I

RELATIONSHIP BETWEEN CLINICAL ACTIVITY OF JOINTS IN RHEUMATOID ARTHRITIS AND VARIATIONS IN THE HISTOPATHOLOGICAL APPEARANCES OF SYNOVIAL TISSUE

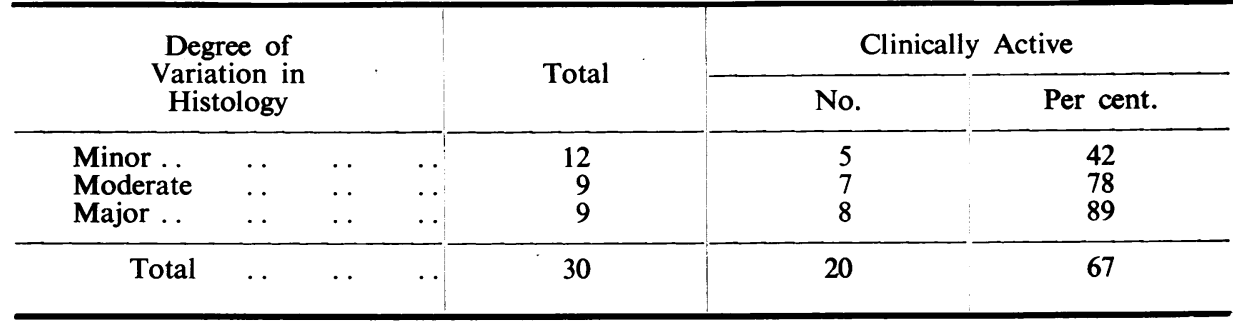

trends were noted. Thus, a much higher proportion of those joints in which major differences were seen were clinically active than of those in which only minor differences were present (Table I). Similarly, nearly three-quarters of the cases showing major differences were of two years' duration or less, whereas more than three-quarters of those showing minor differences were of more than two years' duration. The relationship between the histological changes and the stage of the disease showed the same trend. All the cases with major differences were at Stages I or II, whereas three-quarters of those with minor differences were at Stages III or IV. No relationship was noted between the administration of gold or other drugs (excluding analgesics) and the degree of variation (Table II).

TABLE II

RELATIONSHIP BETWEEN ADMINISTRATION OF GOLD AND OTHER DRUGS IN RHEUMATOID ARTHRITIS AND VARIATIONS IN THE HISTOPATHOLOGICAL APPEARANCES OF SYNOVIAL TISSUE

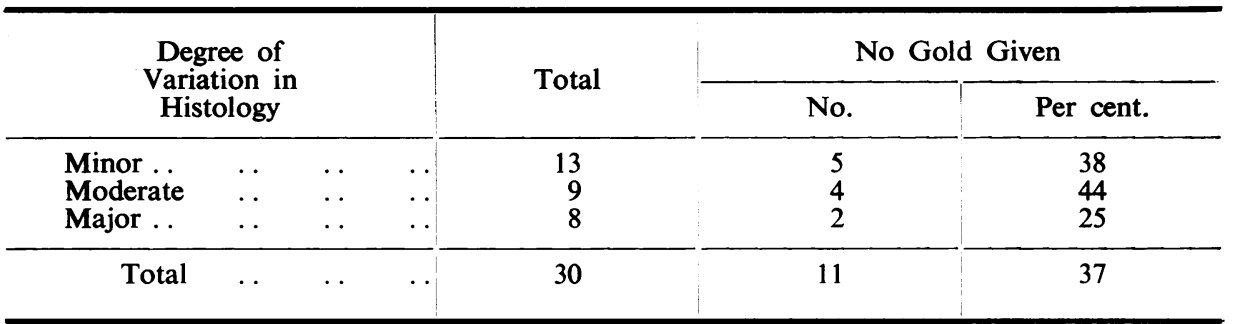

Ankylosing Spondylitis.-The variations in appearance seen here were of minor degree only. This may be due to the fact that a substantial degree of inflammation was seen in only two joints.

Rheumatic Fever.-The appearanoes in two of these joints were normal. In another four, the lesions were mild, consisting of congestion, slight hyperplasia of the synovial cells, minimal round-cell infiltration, and occasional patches of necrosis of the surface. More marked changes, including patches of necrosis in the deeper tissues or slight villous hyperplasia with both round-cell and histiocyte response, were seen in four joints. In only one of these cases had there been a previous attack of rheumatic fever. Two knees showed appearances in different sections, varying from patchy necrosis in one, congestion and slight round-cell infiltration in a second, 


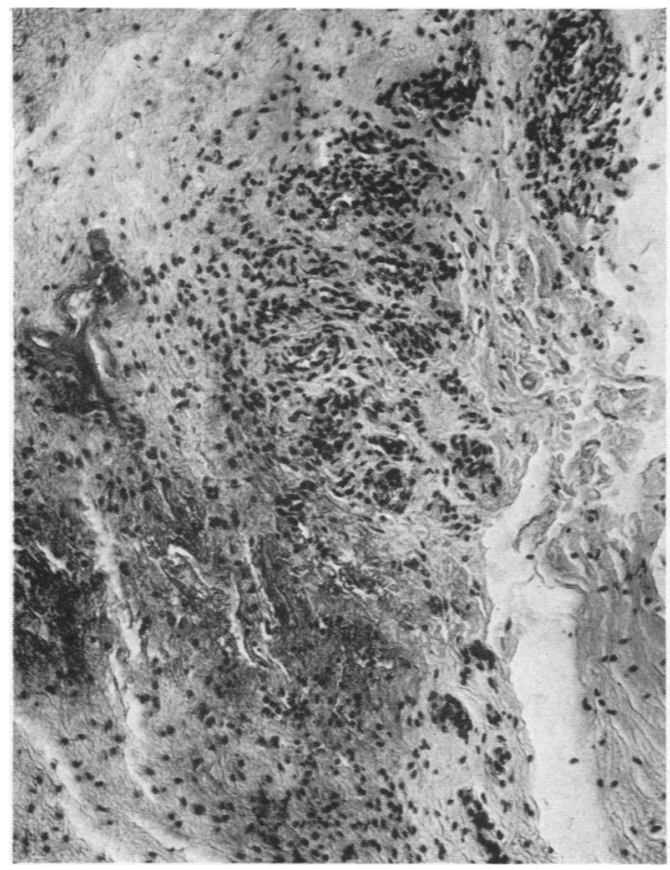

Fig. 5.-Synovial tissue from left elbow. Male, aged 49 . Rheumatic fever of 10 days' duration; previous attack 10 years ago. Large area of necrosis (right) with round-cell response and congestion. $(\times 100$.

to fibrosis in a third (Figs 5-7)

Systemic Lupus Erythematosus.-A wide range of appearances was seen, the mildest lesion resembling that seen in rheumatic fever, whereas in more marked cases there was villous hyperplasia, slight hyperplasia of the surface cells, and more pronounced round-cell infiltration. Minor variations were seen in one joint and marked variations in another. In the latter, one section showed patchy surface necrosis with oedema and slight round-cell infiltration, a second showed acute necrotizing arteritis with marked acute inflammation of the adjacent tissue, and a 
third showed fibrosis (Figs 8-10). These variations were not related to therapy.

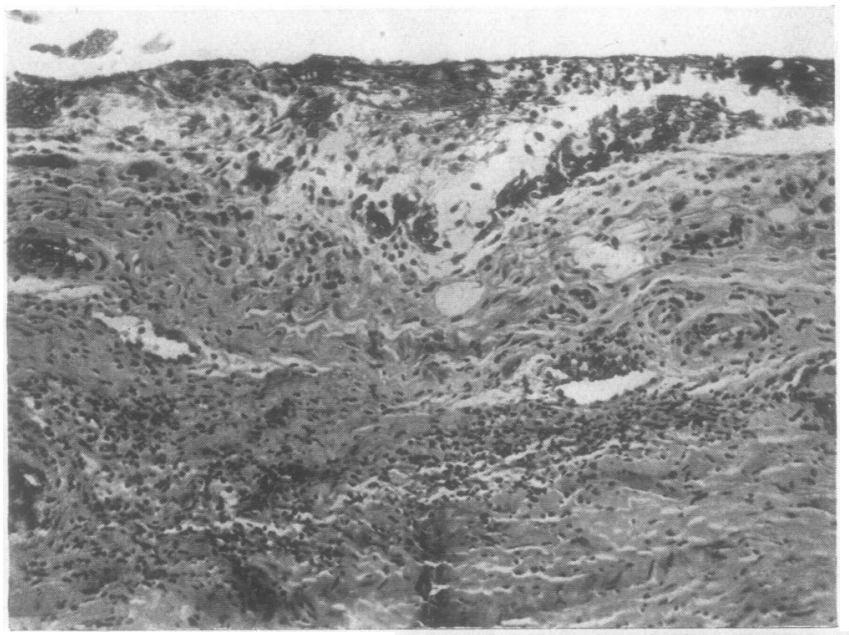

FIG. 8.-Synovial tissue from left knee. Female, aged 45. Systemic lupus erythematosus had affected the knee for 3 months. No response to salicylates; no gold. Necrosis and oedema of surface (top), slight round-cell infiltration below. $(\times 100$.)

Fig. 9.-Same case as Fig. 8. Necrotizing arteritis (bottom, left) and marked acute inflammation of adjacent tissue. $(\times 100$.
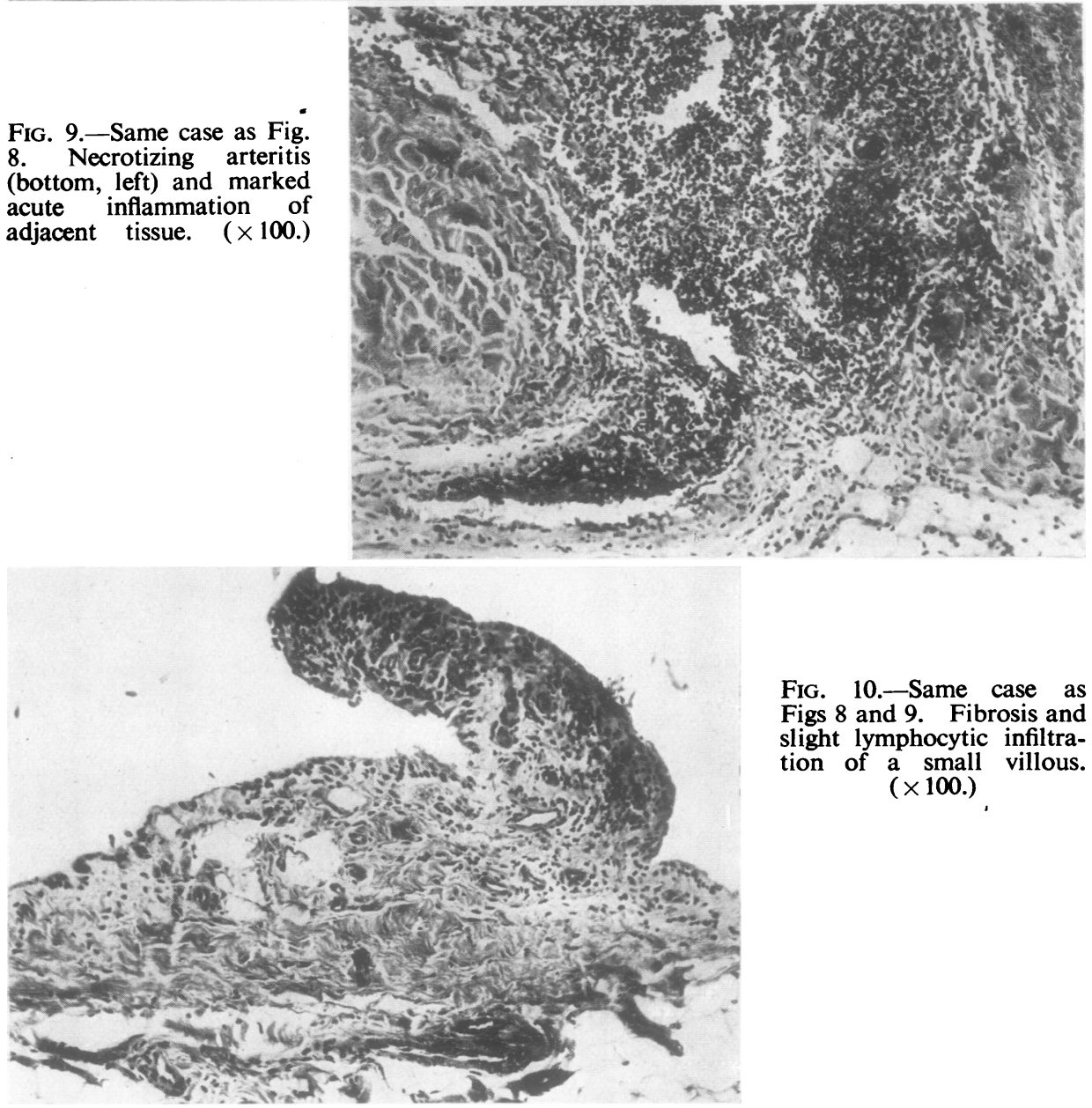

FIG. 10.-Same case as Figs 8 and 9. Fibrosis and slight lymphocytic infiltration of a small villous. $(\times 100$. 
Gout.-Two sections from the knee of a case of gout showed striking differences, inflammation being predominant in one and fibrosis in the other (Figs 11 and 12).

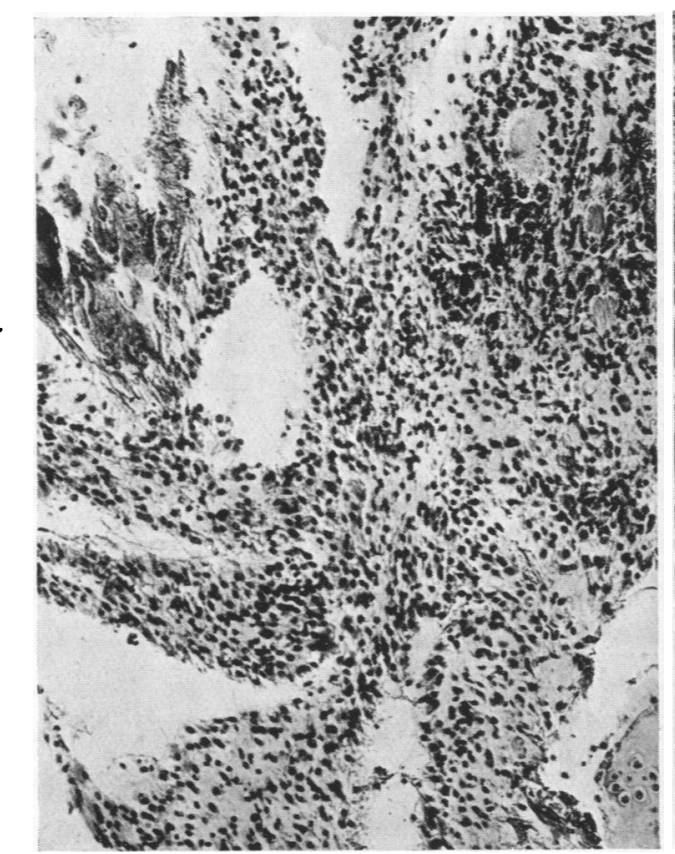

Fig. 11.-Synovial tissue from left knee. Male, Fig. 12.-Same case as Fig. 11. Villous hyperaged 65. Gout of 38 years' duration. Small urate deposits (top, right), marked diffuse roundcell infiltration and hyperplasia of synovial tissue. $(\times 100$.)

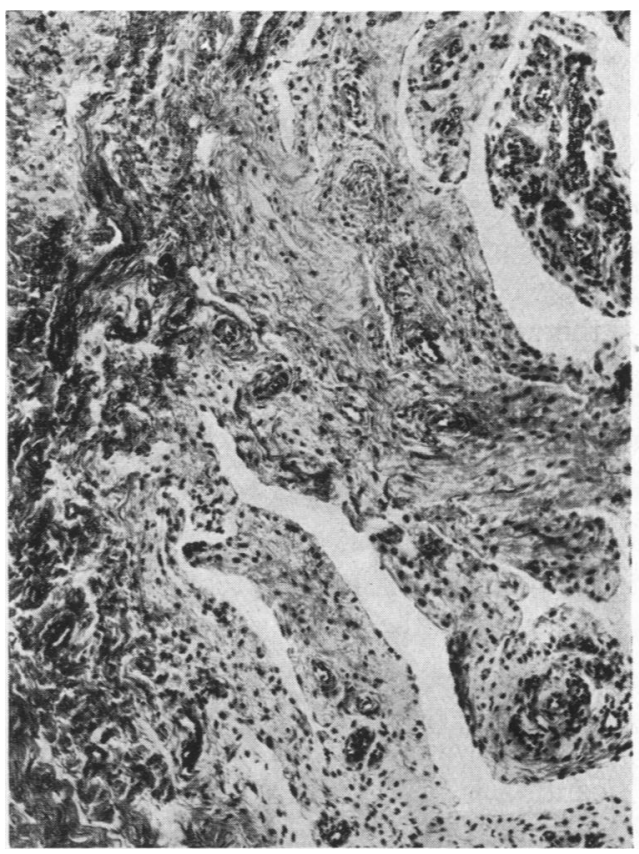

plasia with fibrosis. $(\times 75$.

Polyarteritis Nodosa.-The synovial tissue in two of the joints was normal. In the other two, which were from one patient, occasional arteries and veins showed healed lesions. Slight fibrosis and thrombosis of many capillaries was also seen, but there was no evidence of acute lesions.

\section{Discussion}

This study shows that marked variations in the histopathological appearances in synovial tissue taken from different parts of a joint are not uncommon in rheumatoid arthritis. Minor variations, affecting particularly the relative amounts of inflammation and fibrosis, are frequently seen in this disease. Major differences occur more often than minor ones in cases which are of short duration, clinically active, or at an early stage of the disease, whereas minor variations are more frequent in cases of longer duration, clinically inactive, or at a later stage. The degree of variation in the histopathology is not related to the administration of gold, for in over one-third of those cases where moderate or marked differences occurred, no gold had been given.

Although only slight variations have been noted here in the appearances of sections from joints in ankylosing spondylitis, the close parallel between the 
lesions and the clinical course in that condition and in rheumatoid arthritis suggests that similar variations in histology might be expected to occur in spondylitis.

The lesions which occur in the synovial tissues in most cases of rheumatic fever and systemic lupus erythematosus are such that striking differences in the appearance in different parts of a joint are much less likely to occur than in rheumatoid arthritis. Indeed, Klinge (1930) stressed that extensive search of many blocks of synovial tissue may be necessary in order to make a definite diagnosis of rheumatic fever. Nevertheless, this study has shown that, in both diseases, parts of the synovial tissue may show fine fibrosis, whereas in other parts recent necrosis and inflammation may be seen. In neither disease could the appearances be correlated with drug therapy. The synovial lesions in polyarteritis nodosa show the same patchy distribution as appears elsewhere in the body in this disease. Furthermore, it is to be expected that vessels in the synovial tissue, like those in other tissues, may show all stages of the disease, from acute necrotizing arteritis to completely healed lesions, even in unhealed cases.

In this investigation all the changes in synovial tissue reported in cases of rheumatoid arthritis receiving cortisone or ACTH, have been seen to occur naturally in the course of the disease. Although the administration of these drugs may produce a dramatic clinical response, much caution must be exercised in attributing to them, or to any other drugs which may be introduced in the future, changes which may, in fact, occur in the natural course of the disease. The same caution is necessary in other diseases which respond to the same drugs, such as systemic lupus erythematosus, rheumatic fever, gout, and ankylosing spondylitis.

\section{Summary}

(1) Multiple blocks have been taken at one time from different parts of sixty joints, 35 being affected by rheumatoid arthritis, six by ankylosing spondylitis, ten by rheumatic fever, four by systemic lupus erythematosus, one by gout, and four by polyarteritis nodosa.

(2) Major variations were seen in the histopathological appearances in different regions of ten of the joints from rheumatoid arthritis. Variations in the relative degrees of inflammation and fibrosis, which might be interpreted as indicative of activity and healing respectively, were seen in eight joints. Similar variations were also seen in adjacent blocks taken from the same region of one joint and sometimes in a single section.

(3) Minor variations in degrees of inflammation and fibrosis were seen in two joints in rheumatic fever, two in systemic lupus erythematosus, and one in gout.

(4) These variations were not related to treatment, but had occurred naturally in the course of the diseases. Similar changes in rheumatoid arthritis have been attributed by some authors to the action of cortisone and ACTH, but caution should be exercised in attributing to drugs changes which are known to occur naturally in the synovial tissue in the course of rheumatic diseases.

This work was carried out during the tenure of a research grant from the Nuffield Foundation and of the Hastilow Research Scholarship in Rheumatism, University of Edinburgh. I am grateful to Professor A. M. Drennan for granting facilities for this work 
and for his interest and criticism. I wish to thank various members of the technical staffs of the Pathology Departments of the University and Royal Infirmary of Edinburgh for preparing the sections. The photomicrographs were prepared by Mr. T. C. Dodds.

\section{REFERENCES}

Allison, N., and Ghormley, R. K. (1931). “Diagnosis in Joint Disease”, p. 134. Wood, New York. Collins, D. H. (1949). Proc. R. Soc. Med., 42, 731.

Cruickshank, B. (1951). Annals of the Rheumatic Diseases, 10, 393.

Giansiracusa, J. E., Ropes, M. W., Kulka, J. P., and Bauer, W. (1951). Amer. J. Med., $10,419$.

Ghormley, R. K. (1938). In "A Survey of Chronic Rheumatic Diseases", ed. R. G. Gordon and others, p. 73. Oxford University Press, London.

Hench, P. S., Kendall, E. C., Slocumb, C. H., and Polley, H. F. (1950). Arch. intern. Med., 85, 545.

Jordan, E. P. (1938). Arch. Path., Chicago, 26, 274.

Key, J. A. (1932). In "Special Cytology", ed. E. V. Cowdry, Vol. 2, p. 1055. Hoeber, New York. Klinge, F. (1930). Virchows Arch., 279, 1.

Parker, F., and Keefer, C. S. (1935). Arch. Path., Chicago, 20, 507.

Polley, H. F., and Bickel, W. H. (1951). Proc. Mayo Clin., 26, 273.

Rosenberg, E. F. (1949). In “Comroe's Arthritis”, ed. J. L. Hollander, 4th ed., p. 123. Kimpton, London.

Steinbrocker, O., Traeger, C. H., and Batterman, R. C. (1949). J. Amer. med. Ass., 140, 659.

Interprétation des prélèvements multiples du tissu sinovial dans l'arthrite rhumatismale

\section{RÉSUMÉ}

(1) Des tranches multiples furent prélevées à un moment donné sur de différentes parties de 60 articulations, dont 35 atteintes d'arthrite rhumatismale, 6 de spondylite ankylosante, 10 de rhumatismale, articulaire aigu, 4 de lupus érythémateux disséminé, une de goutte, et 4 de polyartérite noueuse.

(2) Des variations majeures furent observées dix fois dans l'apparence histo-pathologique de différentes régions de la même articulation des cas d'arthrite rhumatismale. Des variations concernant l'intensité relative d'inflammation et de fibrose, pouvant être interprétées respectivement comme signes d'activité ou de guérison, furent observées dans huit articulations. On vit aussi des variations similaires dans les tranches adjacentes prélevées sur la même partie d'une articulation et quelquefois dans la même coupe.

(3) Des variations de moindre importance concernant l'intensité d'inflammation et de fibrose furent notées dans deux articulations des cas de rhumatisme articulaire aigu, deux fois dans le lupus érythémateux disséminé, et une fois dans la goutte.

(4) Ces variations n'étaient pas liées au traitement mais s'étaient présentées spontanément au cours des maladies. Certains auteurs avaient attribué des altérations similaires dans l'arthrite rhumatismale à l'action de la cortisone et de l'ACTH; il est donc nécessaire d'être prudent lorsqu'on attribue aux médicaments des modifications susceptibles de se produire naturellement dans le tissu synovial au cours des affections rhumatismales.

\section{La interpretación de biopsias multiples del tejido sinovial en la artritis reumatoide}

\section{SUMARIO}

(1) Biopsias multiples fueron hechas en un momento determinado en partes diferentes de 60 articulaciones, 35 de ellas de casos de artritis reumatoide, 6 de espondilitis anquilosante, 10 de reumatismo poliarticular agudo, 4 de lupus eritematoso diseminado, una de gota, y 4 de poliarteritis nodosa.

(2) Variaciones de mayor importancia fueron observadas diez veces en la apariencia histopatológica de diferentes regiones de la misma articulación en casos de artritis reumatoide. Variaciones de la intensidad relativa de inflamación y de fibrosis, expuestas a la interpretación de actividad o de cura según el caso, fueron vistas en ocho articulaciones. Viéronse también variaciones semejantes en fragmentos adyacentes recogidos en la misma parte de una articulación $y$, a veces, en el mismo corte.

(3) Variaciones de menor importancia respecto a la intensidad de inflamación y de fibrosis en la misma articulación, fueron observadas dos veces en el reumatismo poliarticular agudo, dos veces en el lupus eritematoso diseminado y una vez en la gota.

(4) Estas variaciones no se relacionaban con el tratamiento sino ocurrían naturalmente en el curso de la enfermedad. Alteraciones similares en la artritis reumatoide habían sido atribuidos por algunos autores a la acción de la cortisona y de la ACTH; hay, pues, que tener cuidado, cuando se atribuye a medicamentos las alteraciones que se sabe capaces de ocurrir en el curso natural de las enfermedades reumáticas. 